\title{
Late Pleistocene and Holocene Vegetation and Climate on the Taymyr Lowland, Northern Siberia
}

\author{
Andrei A. Andreev ${ }^{1}$ and Christine Siegert \\ Alfred Wegener Institute for Polar and Marine Research, Telegrafenberg A43, 14473 Potsdam, Germany \\ Vladimir A. Klimanov \\ Institute of Geography, Russian Academy of Sciences, Staromonetny 29, 109017 Moscow, Russia \\ Aleksandr Yu. Derevyagin and Galina N. Shilova \\ Geological Department of Moscow State University, Vorobievy Gory, 119899 Moscow, Russia \\ and \\ Martin Melles \\ Institute for Geophysics and Geology, Leipzig University, Talstrasse 35, 04103 Leipzig, Germany
}

Received February 6, 2001

Pollen records from perennially frozen sequences provide vegetation and climate reconstruction for the last $48,000{ }^{14} \mathrm{C}$ years in the central part of Taymyr Peninsula. Open larch forest with Alnus fruticosa and Betula nana grew during the Kargin (Middle Weichselian) Interstade, ca. 48,000-25,000 ${ }^{14} \mathrm{C}$ yr B.P. The climate was generally warmer and wetter than today. Open steppe-like communities with Artemisia, Poaceae, Asteraceae, and herb tundralike communities with dwarf Betula and Salix dominated during the Sartan (Late Weichselian) Stade, ca. $24,000-10,300{ }^{14} \mathrm{C}$ yr B.P. The statistical information method used for climate reconstruction shows that the coldest climate was ca. $20,000-17,000{ }^{14} \mathrm{C}$ yr B.P. A warming (Allerød Interstade?) with mean July temperature ca. $1.5 \mathrm{C}$ warmer than today occurred ca. $12,000{ }^{14} \mathrm{C}$ yr B.P. The following cooling with temperatures about $3 \circ-4 \mathrm{C}$ cooler than present and precipitation about $100 \mathrm{~mm}$ lower corresponds well with the Younger Dryas Stade. Tundra-steppe vegetation changed to Betula nana-Alnus fruticosa shrub tundra ca. $10,000{ }^{14} \mathrm{C}$ yr B.P. Larch appeared in the area ca. $9400{ }^{14} \mathrm{C}$ yr B.P. and disappeared after $2900{ }^{14} \mathrm{C}$ yr B.P. Cooling events ca. 10,500 , 9600, and $8200{ }^{14} \mathrm{C}$ yr B.P. characterized the first half of the Holocene. A significant warming occurred ca. $8500{ }^{14} \mathrm{C}$ yr B.P., but the Holocene temperature maximum was at about $6000-4500{ }^{14} \mathrm{C}$ yr B.P. The vegetation cover approximated modern conditions ca. $2800{ }^{14} \mathrm{C}$ yr B.P. Late Holocene warming events occurred at ca. 3500, 2000, and $1000{ }^{14} \mathrm{C}$ yr B.P. A cooling (Little Ice Age?) took place between 500 and 200 ${ }^{14} \mathrm{C}$ yr ago. ๑) 2002 University of Washington.

\footnotetext{
${ }^{1}$ To whom correspondence should be addressed. E-mail: aandreev@awipotsdam.de.
}

Key Words: pollen; vegetation and climate reconstruction; Late Pleistocene; Holocene, Arctic Russia; Taymyr Peninsula.

\section{INTRODUCTION}

The Arctic is highly sensitive to climate variations and is consequently an important region for understanding present and past climate changes. The Taymyr Peninsula, situated in a transition zone between marine-influenced West Siberia and the more continental East Siberia, is a region which is particularly sensitive to climate fluctuations. The Late Pleistocene environment of the Taymyr has been the subject of continuous debate, mostly due to a lack of empirical data. Theoretically based hypotheses propose that a huge Arctic Ice Sheet covered the area during the Late Pleistocene (Grosswald, 1998). However, field data indicate that the glaciation was restricted to mountain areas (Isaeva, 1984; Faustova and Velichko, 1992).

To improve our knowledge about the Late Quaternary of Central Siberia, a multidisciplinary German-Russian research project, "Taymyr," was established in 1993. Within the scope of the project, palynological studies were carried out at a number of sites along a transect from the vicinity of Norilsk in the south to the Taymyr Lake in the north (Hahne and Melles, 1997, 1999; Kienel et al., 1999; Siegert et al., 1999). The transect covers vegetation zones from the arctic tundra to the northern taiga (Fig. 1). In this paper we present the vegetation and climate history for the Labaz Lake area (Fig. 1) during the last 48,000 yr based on 10 pollen profiles. 


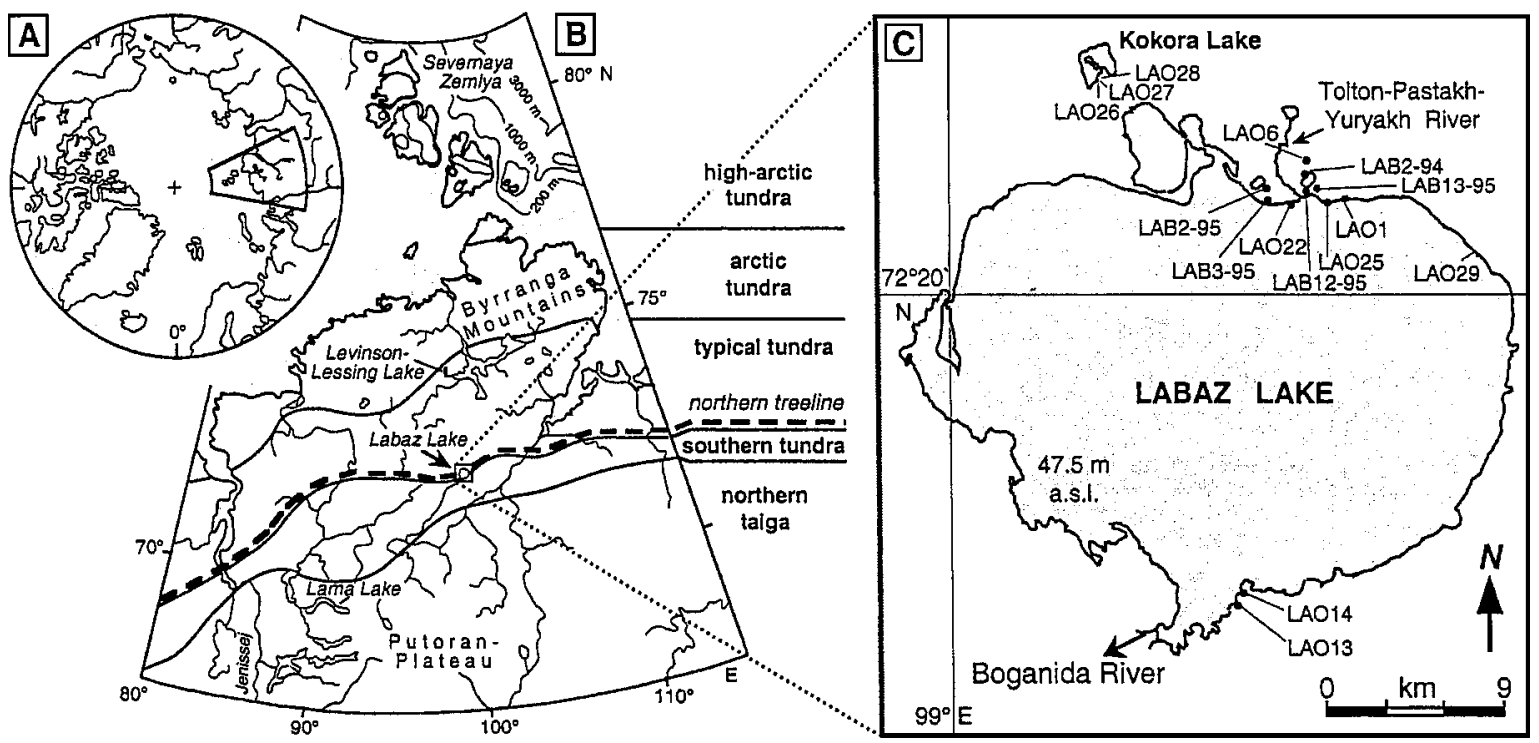

FIG. 1. (A) Map of the Arctic. (B) Map of Taymyr-Severnaya Zemlya region. (C) Overview map of Labaz Lake area with investigated sites.

\section{STUDY AREA}

Labaz Lake $\left(72^{\circ} \mathrm{N}, 99^{\circ} \mathrm{E}\right)$ is one of the largest lakes in the North Siberian Lowland (Fig. 1). The modern lake can be regarded as a relic of a huge ice-dammed "pre-Labaz Lake" (Siegert et al., 1999). The geological and cryolithological structures of the sediments reflect no glaciation after the Zyryan (Early Weichselian) Glaciation. Late Pleistocene landscape changes were connected with the decay of Zyryan-age glaciers.
Changes in the size and level of the pre-Labaz Lake, thermoerosion, and thermokarst processes formed the modern Labaz Lake, a number of smaller lakes, and terraces in the area. Late Pleistocene and Holocene sediments include lacustrian and fluviolacustrian sands, silts, clay, and peat deposits (Siegert et al., 1999).

Climate is characterized by long ( 8 -month), severe winters and short, cold summers. The modern climate characteristics for the area are ca. $10^{\circ}$ to $12^{\circ} \mathrm{C}$ for July temperatures, $-32^{\circ}$ to

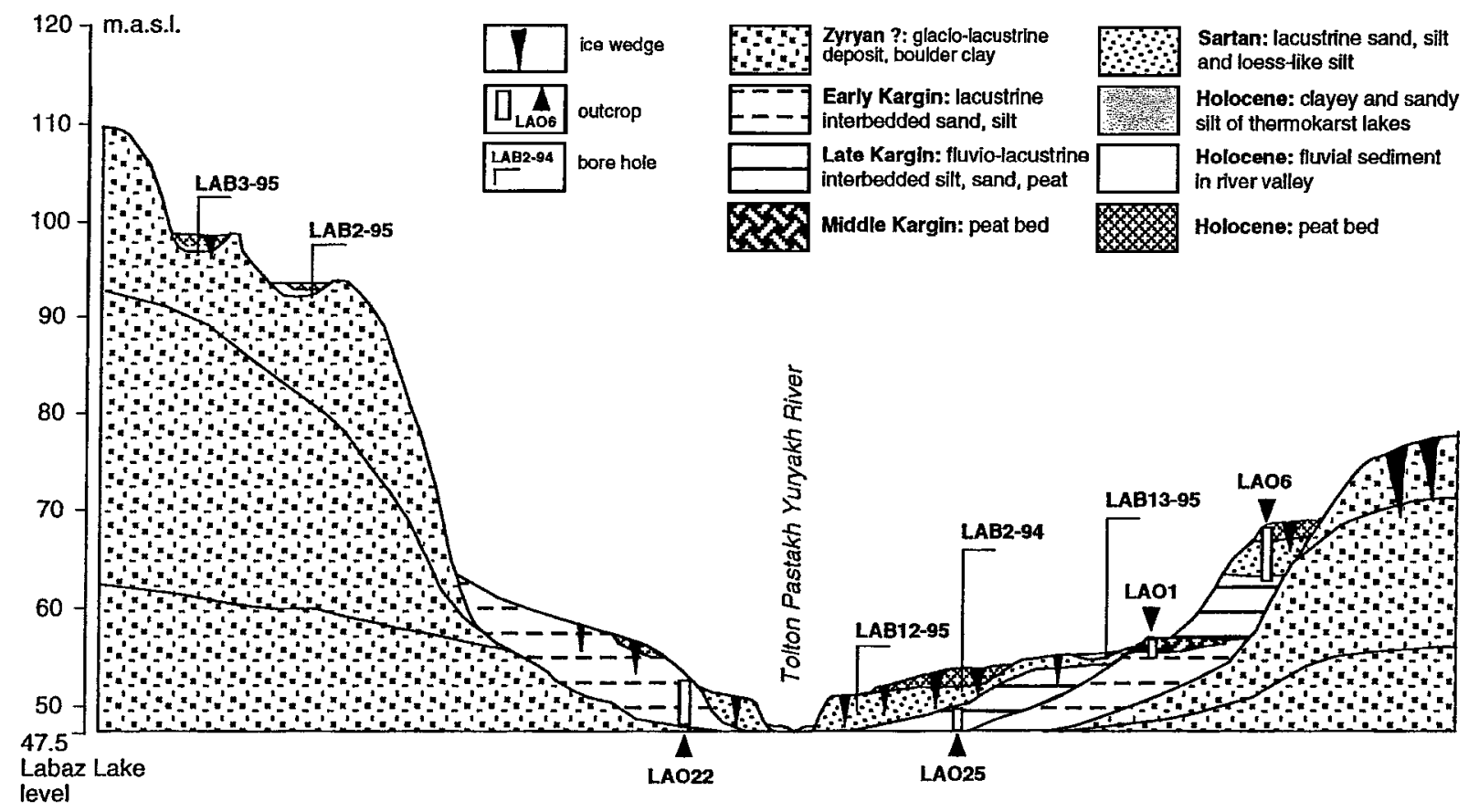

FIG. 2. Generalized section of Late Quaternary sediments in the northern shore of Labaz Lake. 
$-34^{\circ} \mathrm{C}$ for January temperatures, $-12^{\circ}$ to $-14^{\circ} \mathrm{C}$ for annual mean temperature, and about $300 \mathrm{~mm}$ for annual precipitation (Atlas Arktiki, 1985). The frost-free period is ca. 70-75 days per year.

Soils in the area are mainly gleyed cryosols with an active layer of ca. 30-40 cm. Thickness of the permafrost is 300$600 \mathrm{~m}$. Labaz Lake is situated near the boundary of the southern and typical tundra zones. Shrubs, including Betula exilis and Salix ssp. dominate the vegetation. Dwarf shrub species include Vaccinium vitis-idea, Empetrum hermaphroditum, and Dryas punctata. Carex ssp., Eriophorum vaginatum, and mosses such as Tomenthypnum nitens and Drepanocladus uncinatus characterize wetter sites. Alnus fruticosa grow on south-facing slopes. Occasional specimens of Larix dahurica krummholtz were also found near the lake.

\section{METHODS}

Perennially frozen sequences of fluvio-lacustrian sands, silts, clay, and peat sediments were collected from five exposures and five bore holes (Figs. 1 and 2). Sediments were measured, cleaned to expose frozen deposits, and cut for transport into

TABLE 1

Radiocarbon Dates from the Labaz Lake Area Sequences

\begin{tabular}{|c|c|c|c|c|c|c|}
\hline & $\begin{array}{l}\text { Site name, } \\
\text { depth }(\mathrm{cm})\end{array}$ & Dated material & $\begin{array}{c}\text { Age } \\
\left({ }^{14} \mathrm{C} \text { yr B.P. }\right)\end{array}$ & $\begin{array}{c}\delta^{13} \mathrm{C} \\
(\% \circ \mathrm{PDB})\end{array}$ & Laboratory \# & Method \\
\hline 1 & $\mathrm{LAO} 22,250-270$ & Indeterminate woody remains & $>48,000$ & -28.2 & LZ-1271 & LSC \\
\hline 2 & LAO22, 570-610 & Indeterminate woody remains & $>46,000$ & -29.3 & LZ-1272 & LSC \\
\hline 3 & LAO22, 640 & Indeterminate woody remains & $>44,500$ & -29.6 & LZ-1273 & LSC \\
\hline 4 & LAO22, 680-720 & Indeterminate woody remains & $>48,000$ & -28.5 & LZ-1274 & LSC \\
\hline 5 & LAO1, 45-85 & Peat & $>40,000$ & -29.0 & AWI-84 & LSC \\
\hline 6 & LAO $1,85-120$ & Peat & $>40,000$ & -27.4 & AWI-82 & LSC \\
\hline 7 & LAO1, 120-145 & Indeterminate shrub twigs & $>40,000$ & -28.7 & AWI-83 & LSC \\
\hline 8 & LAO1, 120-145 & Indeterminate woody remains & $>48,000$ & -29.0 & LZ-1275 & LSC \\
\hline 9 & $\mathrm{LAO} 25,280$ & Woody peat & $28,500 \pm 400$ & -28.1 & AWI-96 & LSC \\
\hline 10 & $\mathrm{LAO} 25,350$ & Woody peat & $38,000 \pm 600$ & -27.2 & AWI-97 & LSC \\
\hline 11 & $\mathrm{LAO} 25,350$ & Indeterminate shrub twigs & $>40,000$ & -29.4 & AWI-122 & LSC \\
\hline 12 & $\mathrm{LAO} 25,430$ & Indeterminate tree twigs & $33,600 \pm 400$ & -28.1 & AWI-103 & LSC \\
\hline 13 & $\mathrm{LAO} 25,430$ & Indeterminate tree twigs & $38,900 \pm 1300$ & -27.8 & AWI-123 & LSC \\
\hline 14 & $\mathrm{LAO} 25,510$ & Indeterminate shrub twigs & $>40,000$ & -28.8 & AWI-121 & LSC \\
\hline 15 & $\mathrm{LAO} 28,150$ & Indeterminate plant remains & $17,320 \pm 220$ & -27.7 & KIA1413 & AMS \\
\hline 16 & LAO28, 160 & Indeterminate plant remains & $16,710 \pm 60$ & -28.67 & KIA5753 & AMS \\
\hline 17 & LAO6, 60-65 & Peat & $7860 \pm 90$ & -23.5 & LZ-P5 & LSC \\
\hline 18 & LAO6, $110-120$ & Peat & $8760 \pm 90$ & -31.1 & LZ-P6 & LSC \\
\hline 19 & LAO6, 200 & Indeterminate plant remains & $26,240+580 /-540$ & -26.5 & KIA1414 & AMS \\
\hline 20 & LAO6, 240 & Indeterminate plant remains & $14,390+150 /-140$ & -27.7 & KIA1415 & AMS \\
\hline 21 & LAO6, 340-360 & Indeterminate plant remains & $34,500 \pm 900$ & -30.5 & LZ-1269 & LSC \\
\hline 22 & LAO6, 660-680 & Indeterminate plant remains & $38,000 \pm 1600$ & -33.2 & LZ-1270 & LSC \\
\hline 23 & LAO6, 660-680 & Indeterminate plant remains & $29,000 \pm 320$ & -30.0 & AWI-120 & LSC \\
\hline 24 & LAB2-94, 40 & Peaty soil & $2900 \pm 50$ & -28.4 & AWI-105 & LSC \\
\hline 25 & LAB2-94, 36-40 & Peaty soil & $4200 \pm 60$ & -29.4 & LZ-1278 & LSC \\
\hline 26 & LAB2-94, 50-57 & Indeterminate plants remains & $5770 \pm 70$ & -28.16 & KIA1406 & AMS \\
\hline 27 & LAB2-94, 140-150 & Indeterminate plant remains & $6580 \pm 70$ & -28.11 & KIA1407 & AMS \\
\hline 28 & LAB2-94, 225-240 & Indeterminate plant remains & $7360 \pm 60$ & -25.1 & KIA1408 & AMS \\
\hline 29 & LAB2-94, 295-305 & Indeterminate plant remains & $8960 \pm 90$ & -27.9 & KIA1409 & AMS \\
\hline 30 & LAB2-94, 324-332 & Indeterminate plant remains & $8710 \pm 100$ & -28.39 & KIA1410 & AMS \\
\hline 31 & LAB2-94, 365-375 & Indeterminate plant remains & $20,400+300 /-290$ & -29.8 & KIA1411 & AMS \\
\hline 32 & LAB2-94, 379-385 & Indeterminate plant remains & $24,990+520 /-480$ & -26.6 & KIA1412 & AMS \\
\hline 33 & LAB12-95, 98-102 & Peaty soil & $4700 \pm 70$ & -28.9 & LZ-1280 & LSC \\
\hline 34 & LAO13-94, 10 & Peaty soil & $920 \pm 60$ & -26.6 & LZ-P9 & LSC \\
\hline 35 & LAO13-94, 70-80 & Peat & $9280 \pm 100$ & -26.8 & LZ-P10 & LSC \\
\hline 36 & LAO13-94, 135 & Indeterminate plant remains & $11,810 \pm 140$ & -28.0 & KIA1416 & AMS \\
\hline 37 & $\mathrm{LAO} 14,40-45$ & Peaty soil & $6730 \pm 80$ & -28.9 & LZ-P11 & LSC \\
\hline 38 & LAB2-95, 92-104 & Peat & $9150 \pm 130$ & -27.7 & LZ-1279 & LSC \\
\hline 39 & LAB2-95, 92-104 & Indeterminate twigs & $8850 \pm 115$ & -29.1 & LZ-1276 & LSC \\
\hline 40 & LAB3-95, 30-60 & Peat & $2230 \pm 60$ & -27.9 & LZ-1277 & LSC \\
\hline
\end{tabular}

LZ—University Leipzig; AWI-Alfred Wegener Institute, Potsdam; KIA—Leibniz Laboratory, Kiel; LSC—ages obtained by liquid scintillation counting method; AMS—accelerator mass spectrometry. 
TABLE 2

Radiocarbon-Dated Wood Remains from the Labaz Lake Area

\begin{tabular}{|c|c|c|c|c|c|}
\hline \# & Site name and description & Dated material & $\begin{array}{c}\text { Age } \\
\left({ }^{14} \text { C yr B.P. }\right)\end{array}$ & $\begin{array}{c}\delta^{13} \mathrm{C} \\
(\% \circ \mathrm{PDB})\end{array}$ & Laboratory \# \\
\hline 1 & LAO27, steep slope of the Kokora Lake terrace, $400 \mathrm{~cm}$ above the lake & Indeterminate wood remains & $8390 \pm 70$ & -26.7 & AWI-104 \\
\hline 2 & Near the LAB2-95, on a shore of small thermokarst lake & Larix stump & $7790 \pm 60$ & -27.3 & AWI-93 \\
\hline 3 & LAO17, $1050 \mathrm{~cm}$ above the Labaz Lake, under peat bed & Larix trunk & $7230 \pm 90$ & -26.7 & LZ-P15 \\
\hline 4 & LAO26, steep slope of the Kokora Lake terrace, $650 \mathrm{~cm}$ above the lake & Larix trunk & $7170 \pm 100$ & -26.0 & AWI-102 \\
\hline 5 & $\begin{array}{l}\text { LAB1-94, a first terrace of the Tolton-Pastakh-Yuryakh River, under peat } \\
\text { bed, on the } 260-\mathrm{cm} \text { depth }\end{array}$ & Larix trunk & $7010 \pm 80$ & -26.4 & LZ-P21 \\
\hline 6 & $\begin{array}{l}\text { LAO31, first terrace of the Tolton-Pastakh-Yuryakh River on the } \\
\text { 150-cm depth }\end{array}$ & Larix wood & $6360 \pm 80$ & -28.0 & AWI-87 \\
\hline 8 & LAO18, Labaz Lake terrace, on the 100-cm depth & Indeterminate wood remains & $6120 \pm 80$ & -27.3 & AWI-91 \\
\hline 9 & $\begin{array}{l}\text { LAO30, first terrace of the Tolton-Pastakh-Yuryakh River, on the } \\
250-\mathrm{cm} \text { depth }\end{array}$ & Indeterminate wood remains & $5780 \pm 60$ & -27.2 & AWI-101 \\
\hline 10 & LAO15, Labaz Lake terrace, on the $80-\mathrm{cm}$ depth & Indeterminate wood remains & $5710 \pm 100$ & -26.5 & AWI-89 \\
\hline 11 & LAO15, Labaz Lake terrace, on the 80-cm depth & Indeterminate wood remains & $5410 \pm 50$ & -26.5 & AWI-94 \\
\hline 12 & Near the LAO3, on the shore of a small thermokarst lake & Larix trunk & $5220 \pm 80$ & -25.9 & LZ-P3 \\
\hline 13 & In situ in the soil (first terrace of the Tolton-Pastakh-Yuryakh River) & Larix stump & $4780 \pm 80$ & -26.0 & LZ-P2 \\
\hline 14 & LAO29, thermokarst depression on the buried on the $50 \mathrm{~cm}$ depth & Indeterminate wood remains & $3700 \pm 70$ & -27.5 & AWI-88 \\
\hline 15 & Near the LAO24, in a small thermokarst depression & Larix stump & $3680 \pm 70$ & -26.0 & AWI-92 \\
\hline 16 & Near the LAB13-95, in situ, in a small thermokarst depression & Larix stump & $2880 \pm 60$ & -27.6 & AWI-90 \\
\hline
\end{tabular}

LZ-University Leipzig; AWI-Alfred Wegener Institute, Potsdam.

sample bags. Materials for ${ }^{14} \mathrm{C}$ dating were collected separately. A total of 175 samples were analyzed for palynomorphs and 40 samples were radiocarbon dated (Table 1). Woody remains from the sections and from the modern surface were also collected and ${ }^{14} \mathrm{C}$ dated as well (Table 2).

A heavy-liquid separation method (Berglund and RalskaJasiewiczowa, 1986) followed by acetolysis and glycerin mounts was used in Moscow to process samples from nine sections. Samples from the 10th section were processed in Göttingen by a chemical digestion method (Kienel et al., 1999). Pollen percentages were calculated based on the total pollen sum, and percentage of spores was based on a sum of pollen and spores. Pollen zonation was done by visual inspection. The TILIAGRAPH program was used for graphing the pollen data.

The statistical information method has been used to reconstruct climatic changes from fossil pollen spectra (Klimanov, 1976, 1984). This method is based on the statistical correlations between the total pollen and spore abundance, as well as that of tree and shrub pollen in the surface pollen spectra with modern climate conditions around the sampling sites. More than 800 recent pollen spectra from 220 sites across the former USSR were used to work out the technique (Klimanov, 1976). Modern climate variables are taken from the Klimaticheskiy Atlas SSSR (1960). Climatic variables used in the reconstructions comprise mean annual $\left(\mathrm{T}_{\mathrm{yr}}\right)$, January $\left(\mathrm{T}_{\mathrm{I}}\right)$, and July $\left(\mathrm{T}_{\mathrm{VII}}\right)$ temperatures and total annual precipitation.

Treatment of these data by information analyses resulted in the preparation of tables that revealed the correlation of recent pollen data and the four climatic variables (Klimanov, 1976,
1984). Normalized coefficient of contingency for the data (value of correlation between the pollen types and the climatic variables) shows that arboreal pollen taxa provide the best estimate of each climatic characteristic. The statistical relationship existing between recent spectra and present climate conditions can be used to reconstruct past climate. The most probable value of the paleoclimatic variable for a particular pollen spectrum corresponds to the largest sum of the classification criterion obtained from all the pollen in the spectrum (Klimanov, 1984).

The reliability and accuracy of the prepared tables for reconstructing climatic variables were determined by reconstructing present-day mean climate characteristics from modern spectra. The main statistical errors for the reconstructions were $\pm 0.6^{\circ} \mathrm{C}$ for $\mathrm{T}_{\mathrm{yr}}$ and $\mathrm{T}_{\mathrm{VII}}, \pm 1.0^{\circ} \mathrm{C}$ for $\mathrm{T}_{\mathrm{I}}$, and $\pm 25 \mathrm{~mm}$ for precipitation (Klimanov, 1976, 1984). As the method is based mostly on the statistical correlations between the arboreal pollen and modern climate conditions, it works more reliably for the Holocene, in which arboreal pollen dominate in pollen spectra, than for the Late Pleistocene, in which nonarboreal pollen dominated in the spectra.

Conventional ${ }^{14} \mathrm{C}$ dates on bulk sediments and accelerator mass spectrometry ${ }^{14} \mathrm{C}$ dates of terrestrial macrofossils (Table 1) provided chronological control for the investigated sites. Pollen stratigraphy from the well-dated sites was also used for chronological control of the poorly dated sequences. Because we cannot provide good radiocarbon chronological control for all sequences, especially for those of the Late Pleistocene, ages of the reconstructed environmental events are uncalibrated. 


\section{RESULTS AND DISCUSSION}

Ages of the studied sequences span from $>48,000{ }^{14} \mathrm{C}$ yr B.P. to the present. As detailed descriptions of the sites are already published (Siegert et al., 1995, 1996, 1999; Kienel et al., 1999), we will not describe them in this paper but will describe changes in pollen assemblages and possible environmental meanings of these changes.

\section{Kargin (Middle Weichselian) Interstadial}

Generally, the Kargin (Middle Weichselian) sediments are widely distributed in the North Siberian Lowland; they form the lake terraces around the Labaz Lake (Fig. 2). The two best dated sections; LAO22 and LAO25, were studied for pollen and spores. The wood remains from the LAO22 section (Fig. 3) have infinite radiocarbon dates from $>48,000$ to $>44,500{ }^{14} \mathrm{C}$ yr B.P. Similar dates were also obtained from the LAO1 site (Table 1). Betula nana and Alnus fruticosa pollen dominate the pollen spectra in both sites. Rare Larix pollen occurs in the spectra as well. Similar pollen spectra from the adjacent areas are dated from $46,600 \pm 1200$ to $42,600 \pm 1500{ }^{14}$ C yr B.P. (Andreeva, 1982).

Such spectra are almost identical to the surface spectra from northern limit of larch taiga in the Taymyr Peninsula (Clayden et al., 1996) and reflect similar vegetation.

Although Larix is an important species of the forests in northern Eurasia, its history is not well known because of its poor pollen preservation. Larix pollen are rare even in surface samples from larch forests, and their low pollen frequency does not reflect the actual abundance of Larix in the forest (e.g., Vas'kovsky, 1957; Popova, 1961; Clayden et al., 1996). Thus, even rare Larix grains in pollen records are interpreted as the presence of Larix in the local vegetation.

Alnus fruticosa, Betula nana, and Larix grew near Labaz Lake prior to $48,000{ }^{14} \mathrm{C}$ yr B.P. Low concentrations of other tree pollen may reflect long-distance wind transport. However, high concentrations of redeposited Tertiary pollen show that these latter pollen grains were most likely also reworked from older sediments. Lycopodium spores are abundant in the section. They also may be reworked, as Lycopodium spores are more resistant to destruction. Alternatively, Lycopodium also may have grown in the area, as high amounts of Lycopodium spores are characteristic of Holocene sediments from Lama Lake (Hahne and Melles, 1997) and further suggest a northern taiga vegetation around the Labaz Lake area ca. $48,000{ }^{14} \mathrm{C}$ yr B.P.

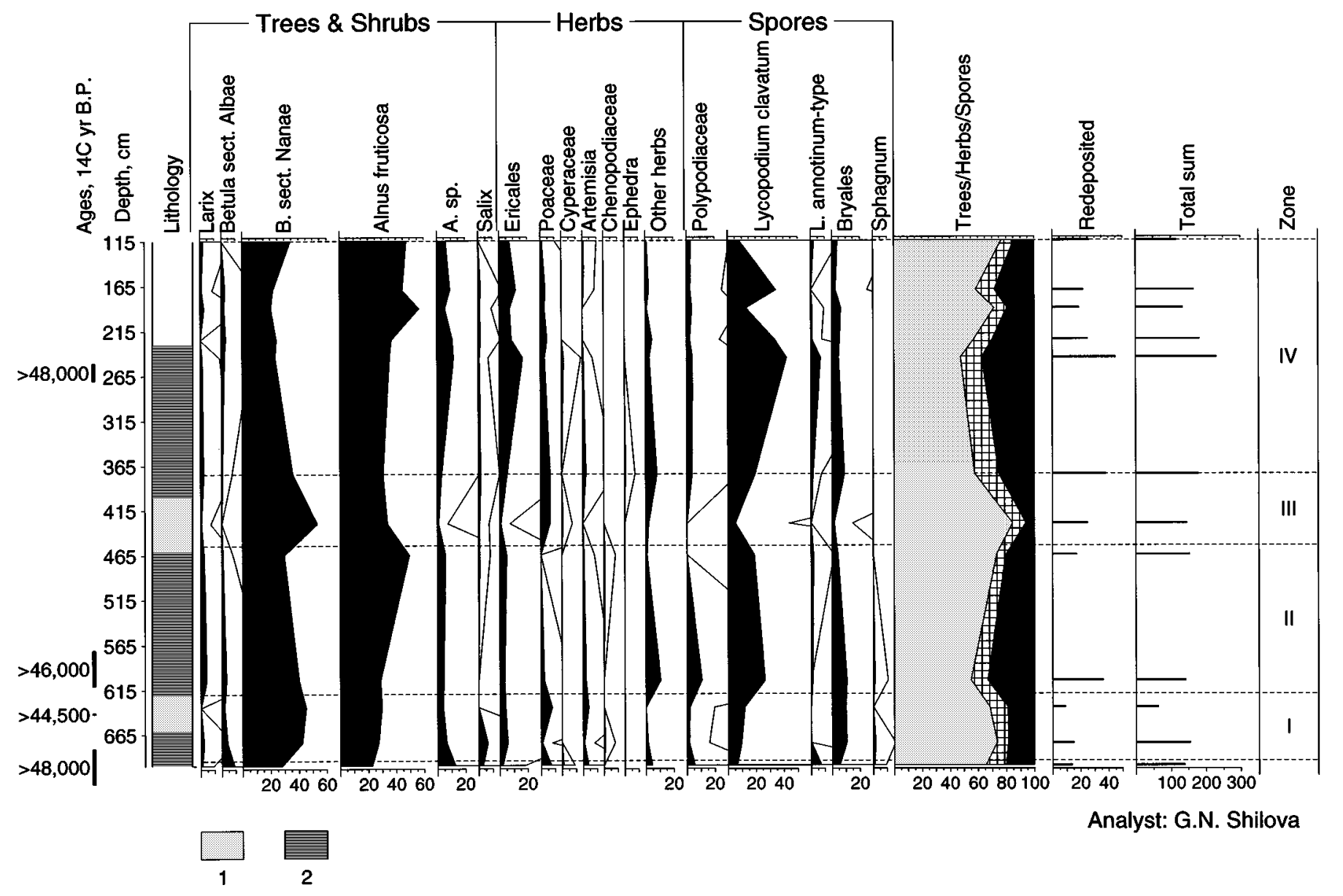

FIG. 3. Percentage pollen and spore diagram of the LAO22 site $\left(72^{\circ} 22^{\prime} 6^{\prime \prime} \mathrm{N}, 99^{\circ} 42^{\prime} 2^{\prime \prime} \mathrm{E}\right)$. 1—sand, 2 - silty clay. 


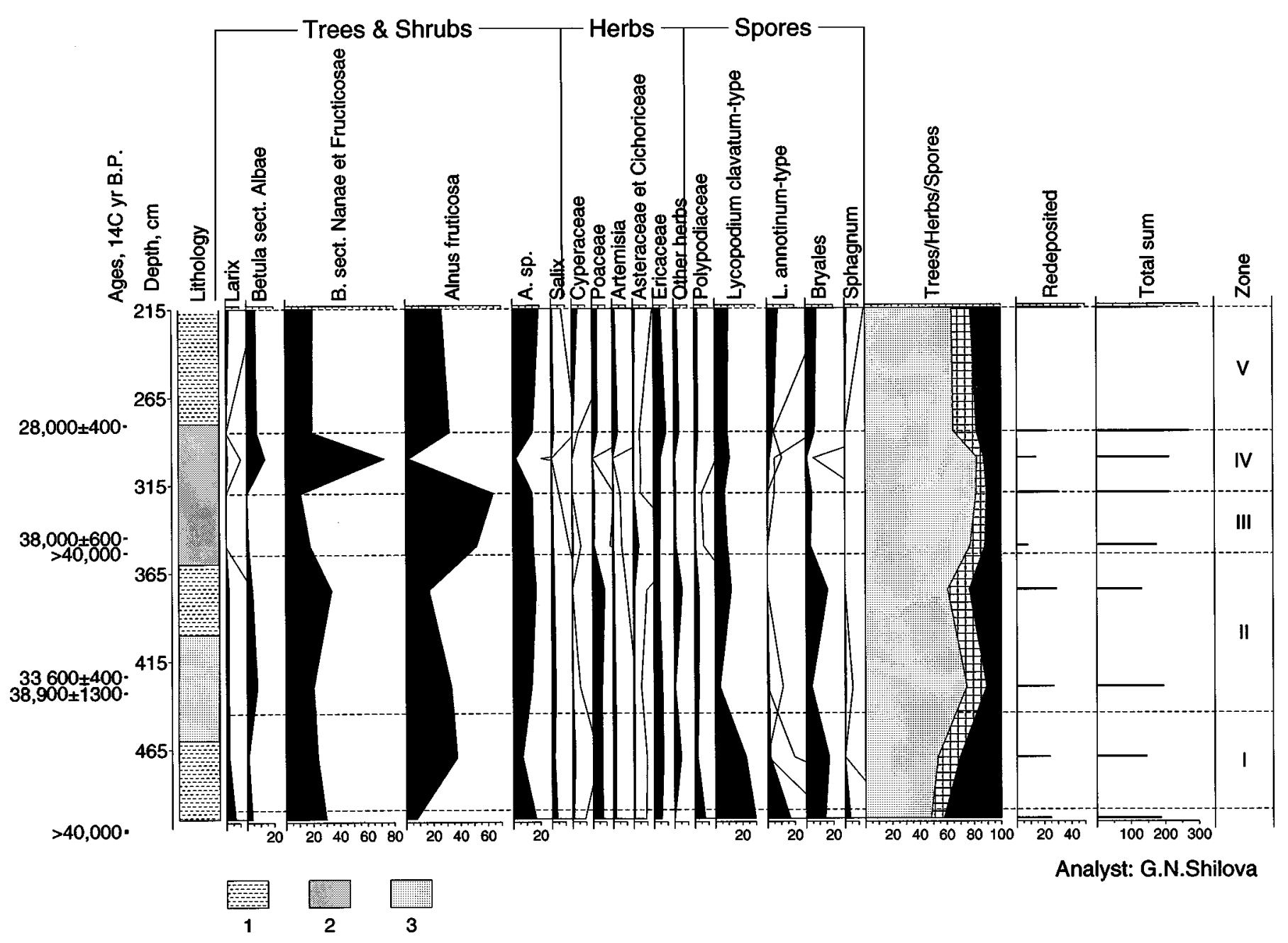

FIG. 4. Percentage pollen and spore diagram of the LAO25 site $\left(72^{\circ} 22^{\prime} 7^{\prime \prime} \mathrm{N}, 99^{\circ} 44^{\prime} 5^{\prime \prime} \mathrm{E}\right)$. 1 — clayey sand, 2 - sand with peat layers, 3 - sand.

Climate reconstructions show that $\mathrm{T}_{\mathrm{yr}}, \mathrm{T}_{\mathrm{I}}$, and $\mathrm{T}_{\mathrm{VII}}$ could be $2.5^{\circ}-3^{\circ} \mathrm{C}$ and precipitation $75-100 \mathrm{~mm}$ higher than today. The actual age of this warming cannot be dated by the radiocarbon method. We suggest it may correspond to the Early Kargin (Early Middle Weichselian) period, ca. 50,00044,000 yr ${ }^{14}$ C B.P. (Isaeva, 1984). Geological evidence confirms this age (Siegert et al., 1996).

Shrub remains from the bottom of the LAO25 section (Fig. 4) were radiocarbon dated to $>40,000{ }^{14} \mathrm{C}$ yr B.P. The pollen spectra from zone I (LAO25) are similar to all spectra from the LAO22 section (Fig. 3) and reflect the similar vegetation. The low content of Alnus fruticosa pollen may reflect deteriorating climate. Climate reconstructions indicate that the climate conditions could be slightly warmer and wetter than today, with $\mathrm{T}_{\mathrm{yr}}$, $\mathrm{T}_{\mathrm{I}}$, and $\mathrm{T}_{\mathrm{VII}}$ ca. $0.5^{\circ} \mathrm{C}$ and precipitation $25 \mathrm{~mm}$ higher than today. The bottom samples in the LAO25 section also indicate the Kargin age, but they could be younger than sediments from LAO22 and might be deposited at the beginning of the middle Kargin warm interval, ca. $44,000-42,000{ }^{14} \mathrm{C}$ yr B.P. (Isaeva, 1984).
The remains of tree branches from a depth of $430 \mathrm{~cm}$ (LAO25) were radiocarbon dated to $38,900 \pm 1300$ and $33,600 \pm 400{ }^{14} \mathrm{C}$ yr B.P. We believe that the younger date is more reliable. The older date probably reflects the reworked character of all macrofossils in the section due to the fluvio-lacustrine (or deltaic) origin of the sediments (Siegert et al., 1999). We assume the pollen spectra from zone II (LAO25) to have an age not older than $33,600{ }^{14} \mathrm{C}$ yr B.P. Open Larix forests with Alnus fruticosa and Betula nana dominated the area at that time. $\mathrm{T}_{\mathrm{yr}}, \mathrm{T}_{\mathrm{I}}$, and $\mathrm{T}_{\mathrm{VII}}$ might be ca. $1.5^{\circ} \mathrm{C}$ and precipitation $50-75 \mathrm{~mm}$ higher than today.

An increase of Betula nana in the upper part of zone II (LAO25) and decrease in Alnus fruticosa percentages indicates vegetation changes. This may indicate that a relative deterioration of climate occurred ca. $32,000{ }^{14} \mathrm{C}$ yr B.P., according to interpolation from the radiocarbon date: $33,600 \pm$ $400{ }^{14} \mathrm{C}$ yr B.P. from the $430-\mathrm{cm}$ depth. This is in good agreement with a cooling on the Taymyr Peninsula at ca. 33,000$30,000{ }^{14} \mathrm{C}$ yr B.P. that was previously noted in radiocarbondated pollen records (Isaeva, 1984). Temperatures might be 
$1^{\circ}-1.5^{\circ} \mathrm{C}$ and precipitation about $25 \mathrm{~mm}$ higher than modern values.

Woody remains from the 350-cm depth (LAO25, bottom of zone III) were ${ }^{14} \mathrm{C}$ dated to $38,000 \pm 600$ and $>40,000$ yr B.P. Because these dates seem to be too old compared with the other dates, suggesting that these macrofossils are reworked, we rejected them. The amount of Alnus fruticosa pollen reaches maximum values, whereas Betula nana percentages are at a minimum in zone III. Such spectra are typical of modern Larix taiga with Alnus fruticosa. All temperatures might be about $2^{\circ} \mathrm{C}$ and precipitation about $100 \mathrm{~mm}$ higher than today. An amelioration of climate may correspond with the beginning of a Late Kargin warming about $30,000{ }^{14} \mathrm{C}$ yr B.P. (Isaeva, 1984). This is well correlated with data from the northern-situated Cape Sabler site, where some boreal plant remains were found in the sample radiocarbon dated to $29,970 \pm 790{ }^{14} \mathrm{C}$ yr B.P. (Kienast et al., 2001).

Betula nana pollen dominate zone IV (LAO25), probably reflecting significant vegetation and climate changes. Shrubby tundra was dominant. Climate was probably similar to that of the present. This relatively cold event may have occurred ca. $28,600-28,800{ }^{14} \mathrm{C}$ yr B.P., according to the $28,500 \pm 400{ }^{14} \mathrm{C}$ yr B.P. date from the $280-\mathrm{cm}$ depth.

Pollen spectra from zone V (LAO25) indicate that the vegetation was similar to the modern Larix taiga near its northern limit.
During this late Kargin warming temperatures might be about $1{ }^{\circ} \mathrm{C}$ and precipitation about $50 \mathrm{~mm}$ higher than today. This is correlated well with data from the Cape Sabler, where macrofossils of boreal elements (e.g., Populus) were found in the sample radiocarbon dated to $26,750 \pm 650{ }^{14} \mathrm{C}$ yr B.P. (Kienast et al., 2001). Kienast estimates that $\mathrm{T}_{\mathrm{VII}}$ could be up to $6^{\circ} \mathrm{C}$ higher than today in the Cape Sabler area.

Because recent cryogenic and soil processes influenced the uppermost part of the LAO25 section it was not studied. Although, Late Kargin sediments from the areas adjacent to Labaz Lake were radiocarbon dated from 30,000 to about $24,000{ }^{14} \mathrm{C}$ yr B.P. (Andreeva and Kind, 1982, Isaeva, 1984), we have no available records for the Late Kargin/Sartan transition.

\section{Sartan (Late Weichselian)}

The Sartan sediments were found in bore holes and sections on the northern shore of Labaz Lake (LAO6, LAB2-94, LAB2-95, LAB12-95, LAB13-95), around Kokora Lake (LAO28), and on the southern shore of Labaz Lake (LAO13 and LAO14) (see Fig. 1). Unfortunately, we do not have good age control for this interval. The most detailed section is LAO6 (Fig. 5), which consists of about $5 \mathrm{~m}$ of silty clay sediments (Siegert et al., 1999). Plant macrofossils from the bottom were ${ }^{14} \mathrm{C}$ dated to $38,000 \pm 1600$ and $29,000 \pm 320{ }^{14} \mathrm{C}$ yr B.P. Both

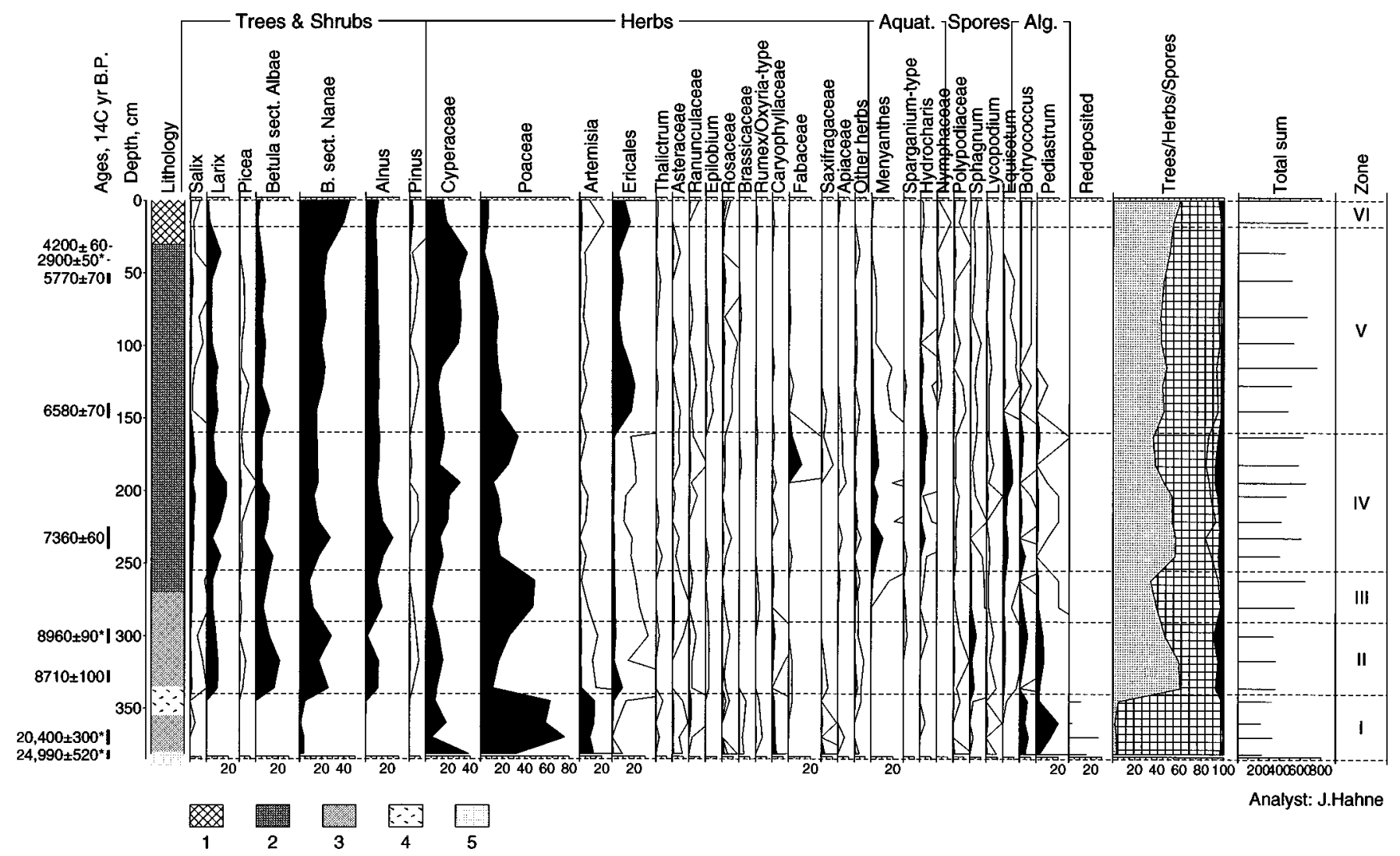

FIG. 5. Percentage pollen and spore diagram of the LAB2-94 site $\left(72^{\circ} 23^{\prime} 18^{\prime \prime} \mathrm{N}, 99^{\circ} 41^{\prime} 15^{\prime \prime} \mathrm{E}\right) .1$ —peaty soil, 2 -peat, 3-loess-like loam, 4 - silt with detritus, 5 -sand. 
dates are too old considering the pollen spectra of the sediments, which contain large amounts of herb pollen including Artemisia, Poaceae, Caryophyllaceae, and Asteraceae. Relatively high content of Larix pollen is noticeable in the lower part of the LAO6 section, especially at the bottom. This may partly reflect the reworked character of the organic matter in the Sartan sediments, confirmed by radiocarbon dating. However, if this was the case, we should have large amounts of Alnus pollen as well. A more likely explanation of the high content of Larix pollen is the existence of a local Larix refuge near the site during the early Sartan. The spectra are very different from those of Kargin, but almost identical to the pollen spectra of Late Glacial deposits from Lama and Levinson-Lessing Lakes (Hahne and Melles, 1997, 1999). Similar character of pollen spectra from the bottom of the LAB2-94 (Fig. 6) and LAO13² sections and from the dated samples of LAO28 site (Table 1), which are radiocarbon dated to the Sartan interval, also confirm the Sartan age of the bottom sediments of LAO6. Generally, Sartan lacustrine and alluvial deposits are widespread in the Eastern Taymyr lowland. Radiocarbon dates obtained from such sediments range from $21,400 \pm 1000$ to $11,600 \pm 200{ }^{14} \mathrm{C}$ yr B.P. (Isaeva, 1984).

The other radiocarbon dates obtained from the Sartan part of LAO6 $\left(34,500 \pm 900,26,240 \pm 580\right.$, and 14,390 $\pm 150{ }^{14} \mathrm{C}$ yr B.P.) are also not in a chronological order, reflecting the reworked character of the dated material. We believe that the earliest date is the most reliable, as there is no evidence of possible contamination of the sediments by earlier organic material, so we assume that the pollen spectra from zone I (LAO6) were deposited during the Sartan.

The plant remains from the bottom part of the LAB2-94 section (zone I, Fig. 6) also show surprisingly old ages, contrasting with the Holocene dates of the overlying sediments. Although the oldest date is from the Late Kargin, the pollen spectra are typical (dominance of Artemisia and Poaceae) for Sartan. Most likely the dated plant remains were reworked from older sediments.

Low pollen concentration and large amounts of reworked Tertiary pollen are typical for Sartan deposits on Taymyr Peninsula (Hahne and Melles, 1997, 1999; Siegert et al., 1999). Numerous unvegetated areas, caused by cryogenic processes, could be possible sources for reworked material. Pollen of plants typical of disturbed soils (e.g., Chenopodiaceae and Asteraceae) are also common in the spectra. The vegetation was probably very discontinuous during the Sartan. Another possible explanation of low pollen concentration might be low pollen productivity of plants due to extreme climate conditions.

The pollen data suggest that open steppe-like plant communities with Artemisia, Poaceae, Asteraceae, and Caryophyllaceae dominated the vegetation around the pre-Labaz Lake.

\footnotetext{
${ }^{2}$ We cannot publish diagrams of all investigated sites in this paper, but detailed diagrams of all sites are available via Word Date Center-A for Paleoclimatology (http://www.ngdc.noaa.gov/paleo/pollen.html).
}

Tundra-like communities with Betula nana, arctic Salix, Dryas, Saxifraga, Oxyria, Carex, and some Brassicaceae (such as Draba) were common in more mesic sites. Rare pollen of trees and other shrubs are most likely reworked from older sediments.

Because of poor dating control and large amounts of reworked pollen, it was difficult to make reliable climate reconstructions for the Sartan interval. However, the data from the LAO6 site indicate that the coldest climate occurred ca. $20,000-17,000{ }^{14} \mathrm{C}$ yr B.P. Temperatures could be $4^{\circ}-5^{\circ} \mathrm{C}$ and precipitation about 75-100 mm lower than modern values. Similar characteristics were obtained from the LAO28 site spectra dated to $17,320 \pm$ 220 and $16,710 \pm 60{ }^{14} \mathrm{C}$ yr B.P.; which were $3^{\circ}-4^{\circ} \mathrm{C}$ below modern values for $\mathrm{T}_{\mathrm{VII}}, 5^{\circ}-5.5^{\circ} \mathrm{C}$ for $\mathrm{T}_{\mathrm{I}}$, and $4^{\circ}-4.5^{\circ} \mathrm{C}$ for $\mathrm{T}_{\mathrm{yr}}$; precipitation was $50-75 \mathrm{~mm}$ lower than modern values.

The late Sartan records are preserved in several sites: LAO6 (Fig. 5), LAO13, LAB13-95, LAO14, LAB12-95, and LAB295. Unfortunately, only two ${ }^{14} \mathrm{C}$ dates, $14,390 \pm 150$ (LAO6) and $11,810 \pm 140{ }^{14} \mathrm{C}$ yr B.P. (LAO13), were obtained from the Sartan part of these sections. Peaks of Betula nana in zone II of LAO6 (Fig. 6) and zone I of LAB12-95, may reflect a warming corresponding to the Allerød. The Arctic Ocean coastline was further to the north compared to today, which contributed to a more continental climate: $\mathrm{T}_{\mathrm{VII}}$ could have been $1.5^{\circ} \mathrm{C}$ warmer than today, $\mathrm{T}_{\mathrm{I}}$ was $1^{\circ} \mathrm{C}$ lower, and $\mathrm{T}_{\mathrm{yr}}$ was close to the modern values. Precipitation was about $25 \mathrm{~mm}$ higher than today. As the method of climate reconstruction is based mostly on the statistical correlations between the modern arboreal pollen and modern climate, the Late Glacial and Holocene climate reconstructions are more reliable than those from the Kargin and especially from the Sartan records. The averaged climate reconstructions for the last $12,000{ }^{14} \mathrm{C}$ yr B.P. are presented in Figure 7.

A decrease of Betula nana pollen percentages and an increase of herb taxa in the upper part of the zone II of LAO6 (Fig. 5) may correspond to the Younger Dryas cooling. Peaks of Artemisia pollen in zone I of LAB13-95 diagram and zone II of LAB12-95 diagram also reflect the deterioration of climate at the late Sartan. Similar herb-dominated pollen spectra from the Kheta River valley were dated to $10,860 \pm 150{ }^{14} \mathrm{C}$ yr B.P. (Nikol'skaya et al., 1980). Temperatures might be about $3^{\circ}-4^{\circ} \mathrm{C}$ and precipitation about $100 \mathrm{~mm}$ lower than modern values (Fig. 7).

\section{Holocene}

The Pleistocene-Holocene transition in the LAO6 (Fig. 5), LAB2-94 (Fig. 6), LAO13, LAB13-95, LAO14, LAB12-95, and LAB2-95 diagrams is characterized by dramatic decreases of herb pollen percentages, especially steppe and tundra taxa (e.g., Artemisia, Dryas, Poaceae, Caryophyllaceae, Asteraceae, Saxifraga). In contrast, significant increase of Betula nana, Alnus fruticosa, and Ericales percentages are noticeable in most diagrams. We do not have radiocarbon dates of this transition, but we assume this interval is ca. $10,300-10,000{ }^{14} \mathrm{C}$ yr B.P., similar to other regions of northern Eurasia (Klimanov, 1996; Velichko et al., 1997; Andreev et al., 1997). 


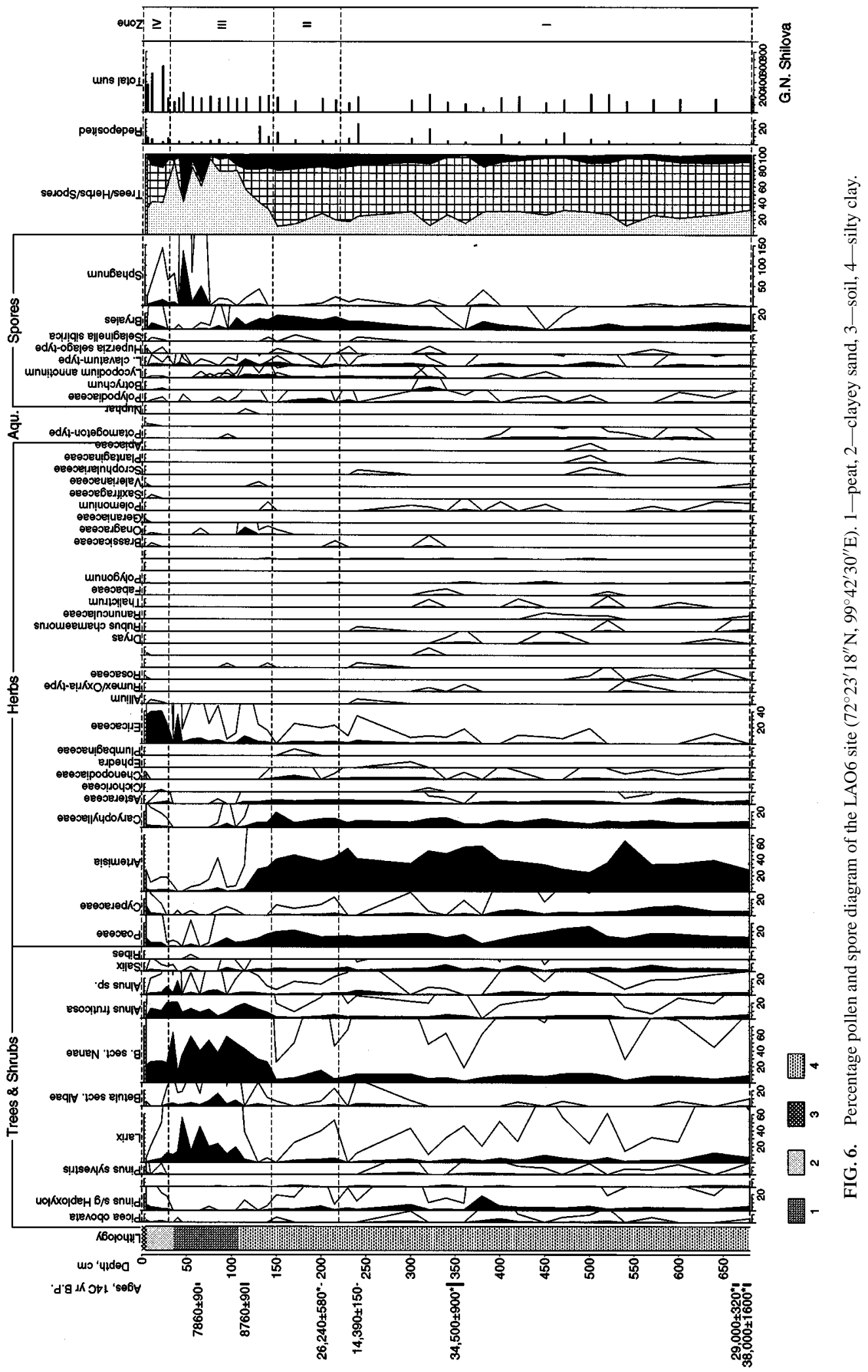




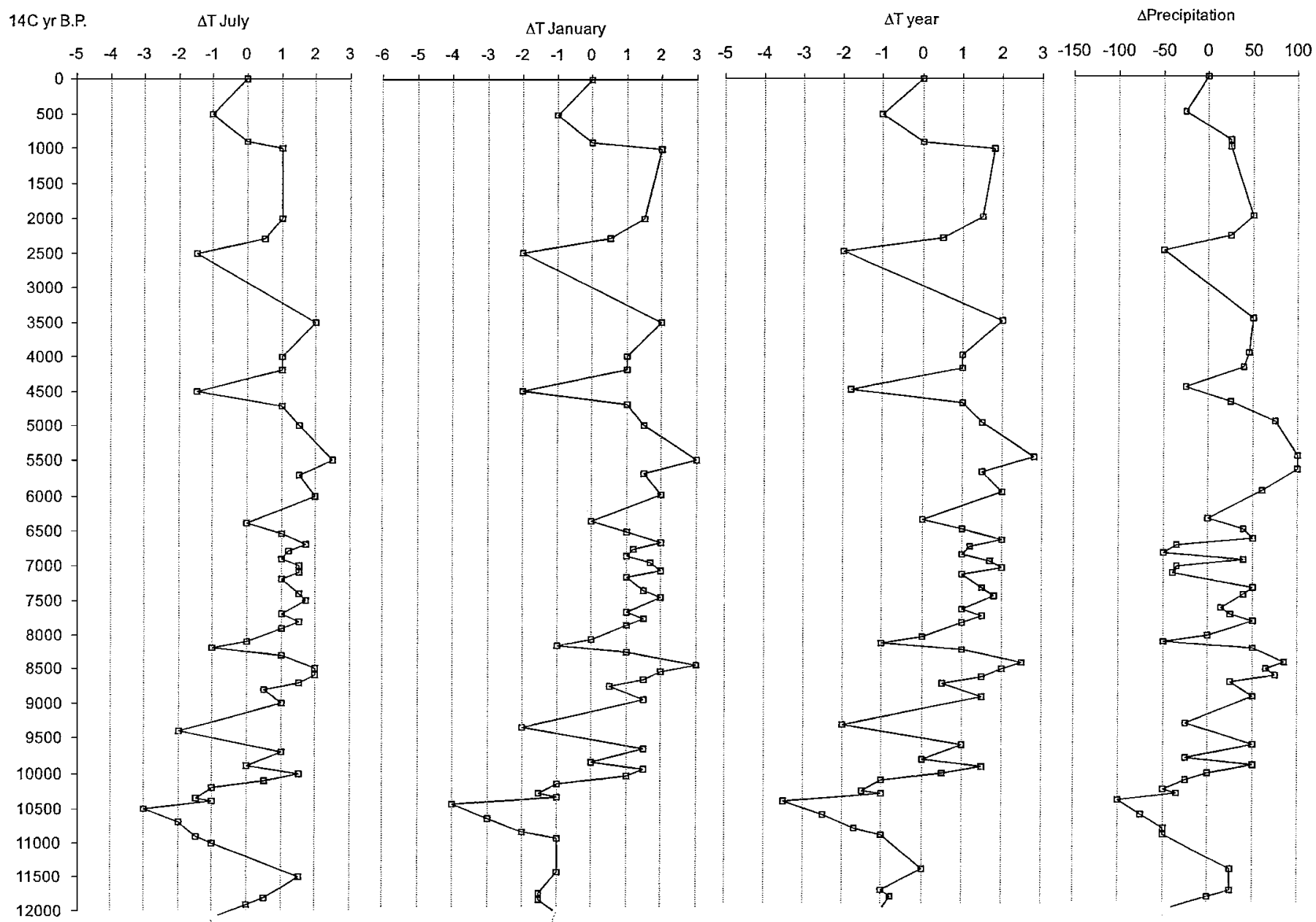

FIG. 7. Averaged paleoclimate curves from Labaz Lake sites pollen.

Sartan tundra-steppe vegetation was replaced by Betula nana-Alnus fruticosa shrub tundra ca. $10,000{ }^{14} \mathrm{C}$ yr B.P. Peaks in Alnus fruticosa pollen percentages appear at different times in the early Holocene pollen records, probably reflecting varying environmental conditions around these sites and/or variation in local pollen depositional characteristics. In the beginning of the Holocene, Alnus fruticos a probably grew only in well-protected places similar to the present situation. The early Preboreal period, at ca. $10,000-9800{ }^{14} \mathrm{C}$ yr B.P. was characterized by temperatures of about $1.5^{\circ} \mathrm{C}$ and precipitation $50 \mathrm{~mm}$ higher than today. At ca. $9600-9300{ }^{14} \mathrm{C}$ yr B.P., temperatures were about $2{ }^{\circ} \mathrm{C}$ and precipitation about $25 \mathrm{~mm}$ below modern values (Fig. 7).

Most likely Larix forest established in the Labaz Lake area at the end of the Preboreal period, at ca. $9200-9000{ }^{14} \mathrm{C}$ yr B.P. The oldest wood remains found in situ in the area were radiocarbon dated to $8390 \pm 70{ }^{14} \mathrm{C}$ yr B.P. (Table 2). However, radiocarbon dates from levels containing Larix pollen in the LAO13 and LAB2-95 sections suggest Larix may have been present as early as $9400-9200{ }^{14} \mathrm{C}$ yr B.P. Dates of $9200 \pm 40,9180 \pm 100$, and $9000 \pm 150{ }^{14} \mathrm{C}$ yr B.P. were obtained from sediments contain- ing pollen and wood of Larix in adjacent areas (Nikol'skaya et al., 1980; Nikol'skaya, 1982). Similar data are known from West Taymyr (Clayden et al., 1997) and West Siberia (Peteet et al., 1998). Probably, Larix and Alnus fruticosa grew only in more protected places by the early Holocene, whereas Betula nana-Salix shrub tundra communities dominated the Labaz Lake area. At the end of Preboreal period $\left(9200-9000{ }^{14} \mathrm{C}\right.$ yr B.P.) $\mathrm{T}_{\mathrm{VII}}$ was about $1^{\circ} \mathrm{C}, \mathrm{T}_{\mathrm{I}}$ and $\mathrm{T}_{\mathrm{yr}}$ about $1.5^{\circ} \mathrm{C}$, and precipitation was about $25 \mathrm{~mm}$ higher than today (Fig. 7).

Increases of Larix and tree Betula pollen content are noticeable in zone III (LAO6) and zone II (LAB2-94) and dated to the middle Boreal period, ca. $8800-8700{ }^{14} \mathrm{C}$ yr B.P. The wood remains (indeterminate pieces of wood, tree Betula bark, Larix cones) from the Kokora Lake vicinity (LAO27) were dated to $8390 \pm 70{ }^{14} \mathrm{C}$ yr B.P. A similar increase in Larix pollen percentages occurred in a peat dated to $8600 \pm 70{ }^{14} \mathrm{C}$ yr B.P. from the Boganida River valley, ca. 50-100 km south of our sites (Nikol'skaya et al., 1980). The ${ }^{14}$ C-dated Larix and Betula remains from the currently treeless tundra on the Taymyr Peninsula show similar ages (Nikol'skaya, 1982; 
MacDonald et al., 2000). Thus, Larix forests with tree Betula were widespread in the area ca. $8600-8400{ }^{14} \mathrm{C}$ yr ago. At that time, the so-called Boreal thermal optimum, temperatures were $2^{\circ}-3^{\circ} \mathrm{C}$ warmer and precipitation $75-100 \mathrm{~mm}$ higher than those of today (Fig. 7). Similar characteristics were obtained by an analog method based on macrofossil data (Koshkarova, 1995). According to these reconstructions $\mathrm{T}_{\mathrm{I}}$ was $4^{\circ}-6^{\circ} \mathrm{C}, \mathrm{T}_{\mathrm{VII}} 2^{\circ} \mathrm{C}$, and summer precipitation about $80 \mathrm{~mm}$ higher than those at present.

A decrease of tree and shrub pollen percentages in the zone III (LAB2-94), Figure 6, may correspond with a cooling at about $8200{ }^{14} \mathrm{C}$ yr B.P. noted in the Northern Eurasia (Klimanov, 1996). Temperatures were about $1{ }^{\circ} \mathrm{C}$ and precipitation about $25 \mathrm{~mm}$ below modern values (Fig. 7).

Shrubs and tree pollen percentages increase again in the sediments dated at about $8000{ }^{14} \mathrm{C}$ yr B.P. (the upper part of the zone III of LAO6, Fig. 5; the bottom part of the zone IV of LAB2-94, Fig. 6), reflecting changes in the vegetation. Most of the dated Larix remains from the area belong to the Atlantic period (Table 2). Tree Betula macrofossils from the Kokora Lake vicinity were dated to $5180 \pm 180{ }^{14} \mathrm{C}$ yr B.P. (Kul'tina et al., 1974). Similar dates of Larix wood were also obtained from adjacent areas (Kremenetski et al., 1998; MacDonald et al., 2000). Minor amounts of Larix and Betula sect. Albae pollen and abundant Alnus fruticosa pollen are also found in spectra from adjacent regions. These assemblages have also been ${ }^{14} \mathrm{C}$ dated to the Atlantic period (Kul'tina et al., 1974; Belorusova and Ukraintseva, 1980; Nikol'skaya et al., 1980; Belorusova et al., 1987). The data show that Larix forest with tree Betula grew in areas that today are dominated by shrub tundra. Alnus fruticosa and dwarf Betula shrub communities were also common. The warmest period during the Holocene occurred ca. $6000-4500{ }^{14} \mathrm{C}$ yr B.P., with maximum temperatures $2.5^{\circ}-3^{\circ} \mathrm{C}$ and precipitation $100 \mathrm{~mm}$ higher than today at about $5500{ }^{14} \mathrm{C}$ yr B.P. (Fig. 7).

Climate characteristics obtained by Koshkarova (1995) on the Taymyr Peninsula for the first half of the Atlantic period (8000-6500 ${ }^{14} \mathrm{C}$ yr B.P.) are similar to ours. $\mathrm{T}_{\mathrm{I}}$ is about $1{ }^{\circ} \mathrm{C}$ higher than at present according to Koshkarova's and $1^{\circ}-2^{\circ} \mathrm{C}$ by our method, and $\mathrm{T}_{\mathrm{VII}}$ is $2^{\circ} \mathrm{C}$ and $1^{\circ}-1.7^{\circ} \mathrm{C}$ higher than at present. Reconstructed precipitation shows a larger difference: 130-180 mm higher than at present according to Koshkarova and only $25-50 \mathrm{~mm}$ by our method. Climatic characteristics for the second half of the Atlantic period $\left(6000-4500{ }^{14} \mathrm{C}\right.$ yr B.P.) show similar differences: $\mathrm{T}_{\mathrm{I}}$ is about $5^{\circ} \mathrm{C}$ and $2^{\circ}-3^{\circ} \mathrm{C}$, and $\mathrm{T}_{\mathrm{VII}}$ is $2^{\circ} \mathrm{C}$ and $1^{\circ}-2.5^{\circ} \mathrm{C}$ higher than at present. Precipitation, reconstructed by Koshkarova, is $50 \mathrm{~mm}$ lower then at present during the winter and $120 \mathrm{~mm}$ higher during summer. Mean annual precipitation, reconstructed by our approach, is $60-100 \mathrm{~mm}$ higher than at present.

The comparison of the climate parameters reconstructed by these different methods shows that $\mathrm{T}_{\mathrm{VII}}$ are very close to each other, whereas the difference in $\mathrm{T}_{\mathrm{I}}$ is greater than that in $\mathrm{T}_{\mathrm{VII}}$. The information statistical method has a better correlation between the modern $\mathrm{T}_{\mathrm{VII}}$ and modern pollen taxa than between $\mathrm{T}_{\mathrm{I}}$ and those. This is probably because all plants experience summer temperature, but most plants are protected from winter frost by snow. It is unclear why precipitation reconstructed by the two methods are rather close in the Boreal period and so different during the first half of the Atlantic period. One possible explanation is that the peat exposures, investigated by Koshkarova, are situated in the area where precipitation is rather high (up to $800 \mathrm{~mm}$ ) at the present, compared with $300 \mathrm{~mm}$ near Labaz Lake. This difference was probably even higher during the Atlantic period.

An increase in Ericales pollen percentages in zone IV (LAB 12-95) and an increase in herbs at the bottom of zone II (LAB395) suggests a significant cooling. This event may be correlated with the cooling at about $4500{ }^{14} \mathrm{C}$ yr B.P., recorded in many sites from northern Eurasia (Klimanov, 1996; Velichko et al., 1997). Koshkarova (1995) also noted the gradual disappearance of the taiga species from the vegetation of modern shrub tundra after $4500{ }^{14} \mathrm{C}$ yr B.P. Temperatures might be about $1.5^{\circ} \mathrm{C}$ and precipitation about $25 \mathrm{~mm}$ below modern values (Fig. 7).

Peat accumulation dramatically slowed or stopped in most sites during the Subboreal period. Processes of erosion and soil formation started on the top of many sequences. The surprisingly old ages from the upper part of LAO6, LAB2-95, LAO13, and LAB2-94 sites as well as an inversion of the radiocarbon dates from the top of LAB2-94 may reflect these processes. Such processes were common in many Arctic regions at this time (Peteet et al., 1998).

Only a few pollen spectra are available for the last millennia (LAB3-95, LAB2-95, LAO13, and LAB2-94), but they reflect the deterioration of environment in the area. Larix was gradually disappearing from the vegetation. The youngest ${ }^{14} \mathrm{C}$ age from larch macrofossils is $2880 \pm 60{ }^{14} \mathrm{C}$ yr B.P. The only published pollen spectrum (a site west from the Labaz Lake) is ${ }^{14} \mathrm{C}$ dated to $3790 \pm 50{ }^{14}$ C yr B.P. (Nikol'skaya et al., 1980). The tundra taxa dominate in the spectrum, indicating modern-type vegetation. Plant remains from a peat profile near the Lama Lake were ${ }^{14} \mathrm{C}$ dated to $2810 \pm 40{ }^{14} \mathrm{C}$ yr B.P. and also demonstrate that modern vegetation and climate was established in that area at the end of the Subboreal period (Koshkarova, 1995). We assume that the vegetation in the Labaz Lake area became similar to modern at the end of the Subboreal period.

Climatic changes during the last several millennia are reflected by only a few samples, with warm events reconstructed at about 3500,2000 , and $1000{ }^{14} \mathrm{C}$ yr ago. The cold event between 500 and $200{ }^{14} \mathrm{C}$ yr ago (Little Ice Age?) is also reconstructed from these records (Fig. 7). Our $\mathrm{T}_{\mathrm{VII}}$ reconstructions for the last $2000{ }^{14} \mathrm{C}$ yr are similar to $\mathrm{T}_{\mathrm{VII}}$ reconstructed from Larix tree rings from eastern Taymyr (Briffa, 1999).

\section{CONCLUSIONS}

Radiocarbon-dated records provide the first detailed vegetation and climate reconstruction for the last $48,000{ }^{14} \mathrm{C} \mathrm{yr}$ in the central part of Taymyr Peninsula (Table 3). Larix forest with shrub Alnus and dwarf Betula grew near Labaz Lake 
TABLE 3

Vegetation and Climate Reconstruction for the Last Radiocarbon 48,000 yr in the Labaz Lake Area

Period, age

Late Holocene, ca. $2500{ }^{14} \mathrm{C}$ yr B.P.-today

Early-Middle Holocene, ca. $9400-2900{ }^{14}$ C yr B.P.

Late Glacial/Holocene transition, ca. $10,000{ }^{14} \mathrm{C}$ yr B.P.

Younger Dryas, ca. $10,500{ }^{14} \mathrm{C}$ yr B.P.

Allerød, ca. $11,500{ }^{14} \mathrm{C}$ yr B.P.

Sartan (Late Weichselian) Stade, ca. $24,000-10,300{ }^{14}$ C yr B.P.

Late Kargin Interstade, ca. $28,000{ }^{14} \mathrm{C}$ yr B.P. or later

Late Kargin Interstade, ca. $28,600-28,800{ }^{14} \mathrm{C}$ yr B.P.

Late Kargin Interstade, ca. $30,000{ }^{14} \mathrm{C}$ yr B.P.

Middle Kargin Interstade, ca. 33,000-30,000 ${ }^{14}$ C yr B.P.

Middle Kargin Interstade, 33,600 ${ }^{14}$ C yr B.P. or prior

Beginning of Middle Kargin Interstade, ca. 44,000$42,000{ }^{14} \mathrm{C}$ yr B.P.

Early Kargin (Middle Weichselian) Interstade, $>48,000{ }^{14} \mathrm{C}$ yr B.P.
Dominant vegetation type

Vegetation became similar to southern tundra type

Open Larix forest with some tree Betula and Alnus fruticosa

Betula nana-Alnus fruticosa shrub tundra Increase of herb presence in vegetation Increase of shrub presence in vegetation Steppe-like communities with Artemisia; Poaceae and tundra communities with Betula nana, Dryas

Vegetation similar to modern Larix taiga near its northern limit

Betula nana dominated vegetation

Larix taiga with Alnus fruticosa

Open Larix forests with Betula nana and some Alnus fruticosa

Larix forests with Alnus fruticosa and Betula nana

Open Larix forests with Betula nana and some Alnus fruticosa

Larix forest with Alnus fruticosa and Betula nana
Climate reconstruction

Coolings at 2500 and $500-250{ }^{14} \mathrm{C}$ yr B.P.

Coolings about 9600,8200 , and $4500{ }^{14} \mathrm{C}$ yr B.P.; warming at $8500{ }^{14} \mathrm{C}$ yr B.P., the warmest interval ca. $8000-4500{ }^{14} \mathrm{C}$ yr B.P.

T up to $1.5^{\circ} \mathrm{C}$ and $\mathrm{P} 50 \mathrm{~mm}$ higher than today T up to $3^{\circ}-4^{\circ} \mathrm{C}$ and $\mathrm{P} 100 \mathrm{~mm}$ less than today

T up to $1.5^{\circ} \mathrm{C}$ and $\mathrm{P} 25 \mathrm{~mm}$ higher than today

$\mathrm{T}$ up to $4^{\circ}-5^{\circ} \mathrm{C}$ and $\mathrm{P} 75-100 \mathrm{~mm}$ less than today during the coldest interval, ca. 18,000-20,000 ${ }^{14} \mathrm{C}$ yr B.P.

$\mathrm{T}$ about $1^{\circ} \mathrm{C}$ and $\mathrm{P}$ about $50 \mathrm{~mm}$ higher than today

Climate similar to modern

$\mathrm{T}$ about $2^{\circ} \mathrm{C}$ and $\mathrm{P}$ about $100 \mathrm{~mm}$ higher than today

Relative deterioration of climate

T up to $1.5^{\circ} \mathrm{C}$ and $\mathrm{P} 50-75 \mathrm{~mm}$ higher than today

$\mathrm{T}$ up to $0.5^{\circ} \mathrm{C}$ warmer and $\mathrm{P} 25 \mathrm{~mm}$ higher than today

T up to $2.5^{\circ}-3^{\circ} \mathrm{C}$ warmer and $\mathrm{P} 75-100 \mathrm{~mm}$ higher than today

$\mathrm{T}$-temperature; $\mathrm{P}$ - precipitation.

during the Kargin (Middle Weichselian) Interstade, ca. 48,000 $25,000{ }^{14} \mathrm{C}$ yr ago. The climate was generally warmer and wetter than today.

Open steppe-like communities with Artemisia, Poaceae, Asteraceae, Cyperaceae, and Caryophyllaceae as well as tundralike communities with dwarf Betula, Arctic Salix, Dryas, Saxifraga, Oxyria, and Carex dominated during the Sartan (Late Weichselian) Stade, about $24,000-10,300{ }^{14} \mathrm{C}$ yr B.P. The coldest climate occurred between $20,000-17,000{ }^{14} \mathrm{C}$ yr B.P. At about $12,000{ }^{14} \mathrm{C}$ yr B.P (the Allerød Interstade?) $\mathrm{T}_{\mathrm{VII}}$ was $1.5^{\circ} \mathrm{C}$ warmer than today. The climate deterioration at the late Sartan corresponds to the Younger Dryas. Temperature could be $3^{\circ}-4^{\circ} \mathrm{C}$ and precipitation about $100 \mathrm{~mm}$ lower than modern values.

Sartan tundra-steppe vegetation was replaced by Betula nanaAlnus fruticosa shrub tundra about $10,000{ }^{14} \mathrm{C}$ yr B.P. Larix appeared in the area about $9400{ }^{14} \mathrm{C}$ yr B.P. and disappeared after $2900{ }^{14} \mathrm{C}$ yr B.P. Coolings at about 9600 and $8200{ }^{14} \mathrm{C}$ yr B.P. characterize the first half of the Holocene. A warm event occurred about $8500{ }^{14} \mathrm{C}$ yr B.P., and the Holocene temperature maximum took place during the second half of the Atlantic period, from 6000 to $4500{ }^{14} \mathrm{C}$ yr B.P. The vegetation cover became similar to that of the present day at the end of the Subboreal period. Late Holocene warm periods occurred at about 3500, 2000, and $1000{ }^{14} \mathrm{C}$ yr B.P. A cooling (Little Ice Age?) took place ca. $250-200{ }^{14} \mathrm{C}$ yr ago.
The climate reconstructions show that the warm periods are defined primarily as times of increased summer temperature rather than winter ones. Precipitation trends parallel the temperature shifts. During warm periods precipitation increased, whereas it decreased during the cold periods. The reconstructed climatic fluctuations are in good agreement with climate events reconstructed from other areas in northern Eurasia. For better resolution climate reconstructions new high-resolution pollen records from the Taymyr Peninsula are necessary.

\section{ACKNOWLEDGMENTS}

This research was made possible through the Helmholtz Association of National Research Centers project, "Natural Climate Variations from 10,000 Years to the Present Day." We would like to thank Drs. P. M. Anderson, D. Yu. Bol'shiyanov, N. Bigelow, and anonymous reviewers for their critical and helpful comments on the manuscript.

\section{REFERENCES}

Andreev, A. A., Klimanov, V. A., and Sulerzhitsky, L. D. (1997). Younger Dryas pollen records from Central and Southern Yakutia. Quaternary International 41-42, 111-116.

Andreeva, S. M. (1982). Northern Siberian Lowland during the Kargin time. Paleogeography, radiocarbon chronology. In "Geokhronologia Chetvertichnogo Perioda” (I. K. Ivanova and N. V. Kind, Eds.), pp. 183-191. Nauka, Moscow. [In Russian] 
Andreeva, S. M., and Kind, N. V. (1982). Kargin deposits. In "Antropogen Taymyra" (N. V. Kind and B. N. Leonov, Eds.), pp. 78-114. Nauka, Moscow. [In Russian]

“Atlas Arktiki” (1985). GUGK, Moscow. [In Russian]

Belorusova, Zh. M., and Ukraintseva, V. V. (1980). Paleogeography of Novaya River (Taymyr Peninsula) during the late Pleistocene and Holocene. Botanicheskiy Zhurnal 65(3), 368-379. [In Russian]

Belorusova, Zh. M., Lovelius, N. V., and Ukraintseva, V. V. (1987). Regional characteristics of the Holocene environmental changes on Taymyr Peninsula. Botanicheskiy Zhurnal 72(5), 610-618. [In Russian]

Berglund, B. E., and Ralska-Jasiewiczowa, M. (1986). Pollen analysis and pollen diagrams. In "Handbook of Holocene Palaeoecology and Palaeohydrology" (B. E. Berglund, Ed.), pp. 455-484. Interscience, New York.

Briffa, K. (1999). Analysis of dendrochronological variability and associated natural climates in Eurasia-the last 10,000 years (ADVANCE-10K). PAGES 7(1), 6-8.

Clayden, S. L., Cwynar, L. C., and MacDonald, G. M. (1996). Stomate and pollen content of lake surface sediments across the tree line on the Taymyr Peninsula, Siberia. Canadian Journal of Botany 74, $1008-1015$

Clayden, S. L., Cwynar, L. C., MacDonald, G. M., and Velichko, A. A. (1997). Holocene pollen and stomate from a forest site on the Taymyr Peninsula, Siberia. Arctic and Alpine Research 29, 327-333.

Faustova, M. A., and Velichko, A. A. (1992). Dynamics of the last glaciation in northern Eurasia. Sveriges Geologiska Undersökning, Seria Ca 81, 113-118.

Grosswald, M. G., (1998). Late-Weichselian ice sheet in Arctic and Pacific Siberia. Quaternary International 45-46, 3-18.

Hahne, J., and Melles, M. (1997). Late and post-glacial vegetation and climate history of the south-western Taymyr Peninsula, Central Siberia, as related by pollen analysis of a core from Lake Lama. Vegetation History and Archaeobotany 6, 1-8.

Hahne, J., and Melles, M. (1999). Climate and vegetation history of the Taymyr Peninsula since Middle Weichselian time-palynological evidence from lake sediments. In "Land-Ocean System in the Siberian Arctic: Dynamics and History" (H. Kassens, H. A. Bauch, I. Dmitrenko, H. Eicken, H.-W. Hubberten, M. Melles, J. Thiede, and L. Timokhov, Eds.), pp. 477-499. Springer-Verlag, Berlin.

Isaeva, L. L. (1984). Late Pleistocene glaciation of north central Siberia. In "Late Quaternary Environments of the Soviet Union" (A. A. Velichko, H. Wright, and K. W. Barnosky, Eds.), pp. 21-30. Univ. of Minnesota Press, Minneapolis.

Kienast, F. W., Siegert, C., and Mai, D.-H. (2001). Climatic implications of late Quaternary plant macrofossil assemblages from the Taymyr Peninsula, Siberia. Global and Planetary Change 31(1-4), 263-280.

Kienel, U., Siegert, C., and Hahne, J. (1999). Late Quaternary palaeoenvironmental reconstructions from a permafrost sequence (North Siberian Lowland, SE Taymyr Peninsula)—A multidisciplinary case study. Boreas 28, 181-193.

Klimanov, V. A. (1976). A technique of quantitative climate reconstruction for the past. Vestnik MGU, Seria Geograficheskaya 2, 92-98. [In Russian]

Klimanov, V. A. (1984). Paleoclimatic reconstruction based on the informationstatistical method. In "Late Quaternary Environments of the Soviet Union"
(A. A. Velichko, H. E. Wright, and C. W. Barnosky, Eds.), pp. 297-303. Univ. of Minnesota Press, Minneapolis.

Klimanov, V. A. (1996). "Climate changes in the Northern Eurasia during the Late Glacial and Holocene reconstructed from pollen records." Doctor of sciences thesis, Institute of Geography, Moscow. [In Russian]

"Klimaticheskiy Atlas SSSR.” (1960). Gidrometeoizdat, Moscow. [In Russian]

Koshkarova, V. L. (1995). Vegetation response to global and regional environmental change on the Taymyr Peninsula during the Holocene. Polar Geography and Geology 19, 145-151.

Kremenetski, C. V., Sulerzhitsky, L. D., and Hantemirov, R. (1998). Holocene history of the northern range limits of some trees and shrubs in Russia. Arctic and Alpine Research 30(4), 317-333.

Kul'tina, V. V., Lovelius, N. V., and Kostyukevich, V. V. (1974). Palynological and geochronological studies of the Holocene sediments in the Novaya River basins on the Taymyr Peninsula. Botanicheskiy Zhurnal 59(9), 264-270. [In Russian]

MacDonald, G. M., Velichko, A. A., Kremenetski, C. V., Goleva, A. A., Andreev, A. A., Borisova, O. K., Cwynar, L. C., Riding, R. T., Forman, S., Edwards, T. W. D., Aravena, R., Hammarlund, D., Szeicz, J. M., and Gattaulin, V. I. (2000). Holocene treeline history and climate change across Northern Eurasia. Quaternary Research 53, 302-311.

Nikol'skaya, M. B. (1982). Paleobotanic and paleoclimatic reconstruction of the Holocene in the Taymyr. In "Antropogen Taymyra" (N. V. Kind and B. N. Leonov, Eds.), pp. 148-157. Nauka, Moscow. [In Russian]

Nikol'skaya, M. B., Kind, N. V., Sulerzhitsky, L. D., and Cherkasova, M. N. (1980). Geochronology and paleophytological characteristics of the Holocene in the Taymyr. In "Geokhronologia Chetvertichnogo Perioda" (I. K. Ivanova and N. V. Kind, Eds.), pp. 176-183. Nauka, Moscow. [In Russian]

Peteet, D., Andreev, A., Bardeen, W., and Mistretta, F. (1998). Long-term Arctic peatland dynamics, vegetation and climate history of the Pur-Taz region, Western Siberia. Boreas 27, 115-126.

Popova, A. I. (I961). Surface pollen spectra of modern vegetation communities of Central Yakutia. In "Materialy po rastytel'nosty Yakutii" (V. L. Komarov, Ed.), pp. 3-6. Publishing House of AN USSR, Leningrad. [In Russian]

Siegert, C., Khrutsky, S. F., and Derevyagin, A. Yu. (1995). Investigation in the Labaz Lake area: Paleogeographical investigation of permafrost. Berichte zur Polarforshung 175, 27-36.

Siegert, C., Derevyagin, A. Yu., and Vannahme, G. (1996). Geocryological and paleogeographical studies in the Labaz Lake area. Berichte zur Polarforshung 211, 28-45.

Siegert C., Derevyagin, A. Yu., Shilova, G. M., Hermischen, W.-D., and Hiller, A. (1999). Paleoclimate indicators from permafrost sequences in the Eastern Taymyr lowland. In "Land-Ocean System in the Siberian Arctic: Dynamics and History" (H. Kassens, H. A. Bauch, I. Dmitrenko, H. Eicken, H.-W. Hubberten, M. Melles, J. Thiede, and L. Timokhov, Eds.), pp. 477-499. Springer-Verlag, Berlin.

Vas'kovsky, A. P. (1957). Pollen spectra of vegetation communities in the extreme Northeast of USSR and their significance for Quaternary vegetation reconstruction. Materialy po geologii i poleznym iskopaemym Severo-Vostoka SSSR 11, 130-178. [In Russian]

Velichko, A. A., Andreev, A. A., and Klimanov, V. A. (1997). The dynamics of climate and vegetation in the tundra and forest zone during the Late Glacial and Holocene. Quaternary International 41-42, 71-96. 